\title{
RESPONSE OF THE EWE TO A HORSE ANTERIOR PITUITARY EXTRACT
}

\author{
N. W. MOORE AND J. N. SHELTON \\ The McCaughey Memorial Institute, Ferilderie, and Department of Animal Husbandry, \\ University of Sydney, N.S.W., Australia
}

(Received 26th Fune 1963)

Summary. A trial of factorial design is described, in which was studied the response of the cyclic ewe to a horse anterior pituitary extract (HAP) Three total-dose levels of HAP $(60,90$ and $135 \mathrm{mg})$ were administered over 2 or 3 days commencing on the 12th day of the oestrous cycle. The total dose was given as either two or three equal daily injections, or four or six equal twice-daily injections.

Highly significant $(P<0.001)$ linear dose-response relationships were observed in the ovulatory response to both 2- and 3-day treatments. Treatment for 3 days was significantly better than treatment for 2 days in the proportion of ewes ovulating $(P<0.05)$, ovulation rates $(P<0.001)$ and fertilization of eggs shed $(P<0.001)$.

For both 2- and 3-day treatments the ovarian responses varied with the time elapsing between the final HAP injection and the onset of oestrus. Maximum responses were observed in ewes in oestrus 24 to $48 \mathrm{hr}$ after the cessation of treatment. Fertilization in ewes treated for 2 days, but not in those treated for 3 days, also varied with the time elapsing between the cessation of treatment and onset of oestrus.

The results showed HAP to be a most effective preparation for the induction of multiple ovulation in the ewe.

\section{INTRODUCTION}

Multiple ovulation may readily be induced in the cyclic ewe by a single injection of pregnant mare serum gonadotrophin (PMS) administered on the 11 th to the 13th day of the oestrous cycle. Robinson (1951a) established doseresponse relationships, but the ovulatory response at all dose levels was highly variable. Anterior pituitary extracts are also capable of inducing multiple ovulation in this species (Hammond, Hammond \& Parkes, 1942; Casida, Warwick \& Meyer, 1944; Murphree, Warwick, Casida \& McShan, 1944; Thibault, Ortavant \& Laplaud, 1948; Moore \& Shelton, 1962). However, little is known of the dose-response relationships following the use of anterior pituitary preparations, or of the optimum method of administration.

In view of the availability of horse anterior pituitaries and the simplicity of the methods of preparing biologically active extracts it seemed desirable to study further the potential value of HAP for inducing multiple ovulation in 
sheep. This paper presents the results of a factorial trial in which was studied the effect of dose of HAP, daily frequency of injection and the duration of treatment on the ovarian response of the cyclic ewe and the subsequent fertilization of eggs shed.

\section{MATERIAL AND METHODS}

\section{Experimental animals}

Seventy-two 5-year-old Merino ewes, run under field conditions and experiencing regular oestrous cycles, were used in the trial which was conducted during the period February-March 1962 (late summer).

\section{Horse anterior pituitary extract}

The extract was prepared from slaughter-house material. Immediately after slaughter the pituitaries were removed, and the posterior lobes dissected out and discarded. No attempt was made to select pituitaries according to sex or whether castrate or not. The anterior lobes were placed on 'dry-ice' and transported to the laboratory for storage at $-20^{\circ} \mathrm{G}$. When enough were available they were finely ground in a frozen state, a $2 \%$ sodium chloride solution was added to the ground material ( $4 \mathrm{ml}$ of solution to $1 \mathrm{~g}$ pituitaries) and the whole was homogenized in a Waring blender for $5 \mathrm{~min}$.

The homogenate was centrifuged at $1500 \mathrm{rev} / \mathrm{min}$ for $20 \mathrm{~min}$ and the supernatant filtered through glass wool. The residue was resuspended and the process repeated once, after which the residue was discarded. The volume of the pooled supernatant was recorded and 4.2 volumes of $95 \%$ ethanol added. After standing for $4 \mathrm{hr}$ the resulting precipitate was washed thoroughy with $95 \%$ ethanol, given a final washing with ether and then left overnight in a vacuum desiccator over phosphorus pentoxide. The dried precipitate was then removed, weighed and stored for use at room temperature.

A total of $655 \mathrm{~g}$ of anterior pituitaries collected from 320 horses yielded $152 \mathrm{~g}$ of extract.

Immediately before use the extract was finely ground and suspended in sterile water at a concentration of $5 \mathrm{mg} / \mathrm{ml}$. It was administered by subcutaneous injection.

\section{Design of the trial}

A factorial design was used (Table 1). All treatments commenced on the morning of the 12 th day after mating with vasectomized rams and were continued for 2 days or 3 days. The total dose of HAP was administered as either two or three equal daily injections, or four or six equal twice-daily injections. Ewes treated once daily were injected at 6 a.m.; those treated twice daily were injected at 6 a.m. and 6 p.m.

\section{Detection of oestrus}

During and after treatment the ewes were run with four active entire Merino rams fitted with Sire-sine harnesses and crayons (Radford, Watson \& Wood, 1960), and inspected for service at 6 a.m. and 6 p.m. 


\section{Laparotomies}

Laparotomies were performed 48 to $84 \mathrm{hr}$ after the ewes were first observed in oestrus. The numbers of recent ovulations and unruptured Graafian follicles of diameter greater than $5 \mathrm{~mm}$ were recorded. Ewes failing to exhibit oestrus by the 9th day after the start of treatment were immediately subjected to laparotomy.

In-vivo egg recovery was carried out by flushing the Fallopian tubes, together with about $5 \mathrm{~cm}$ of the most distal portion of the uterine horns, with sheep serum.

\section{Criteria of fertilization}

Eggs which had cleaved in an apparently normal manner were classed as fertilized. Uncleaved eggs were incubated for up to $8 \mathrm{hr}$ in sheep serum held at $35^{\circ} \mathrm{C}$. Those which divided during incubation were considered to have been fertilized.

TABLE 1

DESIGN OF THE TRIAL

\begin{tabular}{l|l|c|c}
\hline \multicolumn{1}{c|}{ Comparison } & \multicolumn{1}{c|}{ Description } & Factors & Product \\
\hline Total dose HAP & 60 versus 90 versus 135 mg & 3 & 3 \\
$\begin{array}{l}\text { Duration of treatment } \\
\text { Frequency of treatment per day }\end{array}$ & $\begin{array}{l}\text { 2 versus 3 days } \\
\text { daily }\end{array}$ & 2 \\
\hline
\end{tabular}

Number of ewes per group $=$ six. Total ewes $=$ seventy-two.

Analysis of results

Standard $\chi^{2}$ tests and analyses of variance were carried out on the raw or appropriately transformed data.

\section{RESULTS}

Preliminary analysis showed that the frequency of treatment had no significant effect upon any of the factors studied (Table 2). Thus the data for once and twice daily treatment could be pooled as shown in Tables 3,4 and 5 .

\section{Number of ewes in oestrus}

Of the seventy-two ewes treated, sixty-nine were served within 7 days of the beginning of treatment, sixty-four $(93 \%)$ within 5 days. There were no significant treatment effects (Table 2).

\section{Ovarian response}

Ovulations. Laparotomies revealed that sixty-four ewes had ovulated (Table 2 ), twenty-nine of thirty-four which were served after treatment for 2 days and all of the thirty-five served after treatment for 3 days $(P<0.05)$. The three ewes which were not served all failed to ovulate. There was a highly significant linear dose HAP effect on the mean numbers of corpora lutea $(P<0.001)$. 
Duration of treatment also had a highly significant effect $(P<0.001)$, but there was no significant interaction between dose HAP and duration of treat-

TABLE 2

OESTROUS AND OVARIAN RESPONSES TO HAP TREATMENT

\begin{tabular}{|c|c|c|c|c|c|c|}
\hline & \multicolumn{3}{|c|}{ No. ewes } & \multicolumn{2}{|c|}{$\begin{array}{c}\text { Mean No. per treated } \\
\text { ewe }\end{array}$} & \multirow{2}{*}{$\begin{array}{c}\text { Mean time } \\
\text { interval to } \\
\text { oestrus* (hr) }\end{array}$} \\
\hline & Served & $\begin{array}{l}\text { Which } \\
\text { ovulated }\end{array}$ & $\begin{array}{l}\text { With fer- } \\
\text { tilized eggs }\end{array}$ & $\begin{array}{c}\text { Corpora } \\
\text { lutea }\end{array}$ & $\begin{array}{l}\text { Follicles } \\
>5 \mathrm{~mm} \\
\text { diameter }\end{array}$ & \\
\hline $\begin{array}{l}\text { Total dose of HAP }(\mathrm{n}=24) \\
60 \mathrm{mg} \\
90 \mathrm{mg} \\
135 \mathrm{mg} \\
P \text { linear } \\
P \text { quadratic }\end{array}$ & $\begin{array}{l}23 \\
22 \\
24 \\
\text { ns } \\
\text { ns }\end{array}$ & $\begin{array}{l}20 \\
21 \\
23 \\
\text { ns } \\
\mathrm{ns}\end{array}$ & $\begin{array}{l}17 \\
16 \\
20 \\
\text { ns } \\
\text { ns }\end{array}$ & $\begin{array}{l}4 \cdot 3 \\
6 \cdot 6 \\
11 \cdot 3 \\
<0 \cdot 001 \\
\text { ns }\end{array}$ & $\begin{array}{l}2 \cdot 7 \\
2 \cdot 8 \\
3 \cdot 8 \\
\text { ns } \\
\text { ns }\end{array}$ & $\begin{array}{l}84 \text { to } 96 \\
84 \text { to } 96 \\
84 \text { to } 96 \\
\text { ns } \\
\text { ns }\end{array}$ \\
\hline $\begin{array}{l}\text { Duration of treatment } \\
\qquad(\mathrm{n}=36) \\
2 \text { days } \\
3 \text { days } \\
P\end{array}$ & $\begin{array}{l}34 \\
35 \\
\text { ns }\end{array}$ & $\begin{array}{l}29 \\
35 \\
<0.05\end{array}$ & $\begin{array}{c}22 \\
31 \\
<0.05\end{array}$ & $\begin{array}{c}5.2 \\
9.6 \\
<0.001\end{array}$ & $\begin{array}{l}3 \cdot 4 \\
2 \cdot 8 \\
\text { ns }\end{array}$ & $\begin{array}{c}84 \text { to } 96 \\
84 \text { to } 96 \\
\text { ns }\end{array}$ \\
\hline $\begin{array}{l}\text { Frequency of treatment } \\
\text { (n=36) } \\
\text { Once daily } \\
\text { Twice daily } \\
P\end{array}$ & $\begin{array}{l}35 \\
34 \\
\text { ns }\end{array}$ & $\begin{array}{l}32 \\
32 \\
\text { ns }\end{array}$ & $\begin{array}{l}25 \\
28 \\
\text { ns }\end{array}$ & $\begin{array}{c}7 \cdot 5 \\
7 \cdot 3 \\
\text { ns }\end{array}$ & $\begin{array}{l}2 \cdot 7 \\
3 \cdot 5 \\
\text { ns }\end{array}$ & $\begin{array}{l}84 \text { to } 96 \\
84 \text { to } 96 \\
\text { ns }\end{array}$ \\
\hline Totals and means $(n=72)$ & 69 & 64 & 53 & $7 \cdot 4$ & $3 \cdot 1$ & 84 to 96 \\
\hline
\end{tabular}

* Mean time interval between first HAP injection and onset of oestrus.

Figures showing significant differences are in italics.

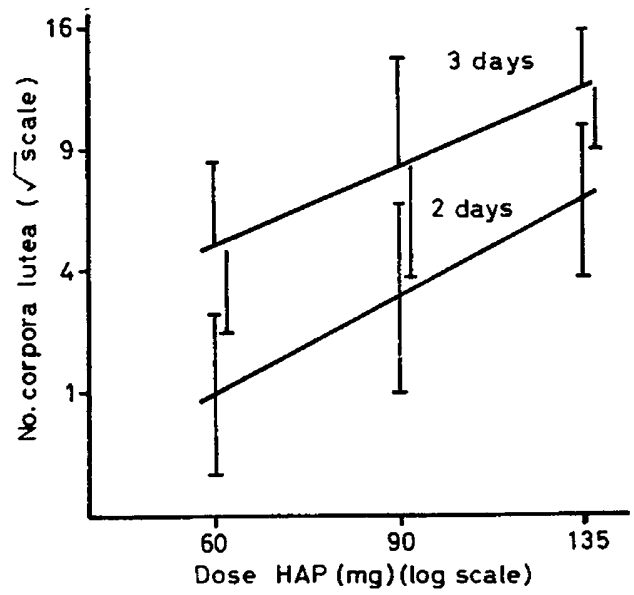

TExr-pIg. 1. Dose-response relationships for HAP given for 2 or 3 days on numbers of corpora lutea.

ment. The dose-response relationships, together with $95 \%$ fiducial limits are presented in Text-fig. 1. 
Unruptured follicles greater than $5 \mathrm{~mm}$ in diameter. There was no significant effect of treatment on the numbers of unruptured follicles. Regardless of the dose of HAP, there was always a residue of few (average three) follicles which failed to

TABLE 3

EFFECT OF HAP TREATMENT ON THE PERGENTAGE OF FOLLIGLES RUPTURED AND OF EGGS FERTILIZED

\begin{tabular}{|c|c|c|c|c|c|c|c|}
\hline \multirow{2}{*}{$\begin{array}{c}\text { Duration of } \\
\text { treatment } \\
\text { (days) }\end{array}$} & \multirow{2}{*}{$\begin{array}{c}\text { Total dose } \\
\text { of HAP }(\mathrm{mg})\end{array}$} & \multirow{2}{*}{$\begin{array}{l}\text { Total ovarian } \\
\text { response (corpora } \\
\text { lutea }+ \text { unruptured } \\
\text { follicles) }\end{array}$} & \multicolumn{2}{|c|}{ Ruptured follicles } & \multicolumn{3}{|c|}{ Eggs } \\
\hline & & & No. & $\%$ & $\begin{array}{c}\text { No. } \\
\text { recovered }\end{array}$ & $\underset{\text { fertilized }}{\text { No. }}$ & $\begin{array}{c}\% \\
\text { fertilized }\end{array}$ \\
\hline 2 & $\begin{array}{r}60 \\
90 \\
135\end{array}$ & $\begin{array}{r}59 \\
91 \\
159\end{array}$ & $\begin{array}{r}25 \\
49 \\
113\end{array}$ & $\begin{array}{l}42 \cdot 4 \\
53 \cdot 8 \\
71 \cdot 1\end{array}$ & $\begin{array}{l}23 \\
39 \\
84\end{array}$ & $\begin{array}{l}22 \\
14 \\
26\end{array}$ & $\begin{array}{l}95 \cdot 7 \\
35 \cdot 9 \\
31 \cdot 0\end{array}$ \\
\hline Total & & 309 & 187 & $60 \cdot 5$ & 146 & 62 & $42 \cdot 5$ \\
\hline 3 & $\begin{array}{r}60 \\
90 \\
135\end{array}$ & $\begin{array}{l}108 \\
133 \\
205\end{array}$ & $\begin{array}{r}77 \\
109 \\
159\end{array}$ & $\begin{array}{l}71 \cdot 3 \\
82 \cdot 0 \\
77 \cdot 6\end{array}$ & $\begin{array}{r}58 \\
88 \\
134\end{array}$ & $\begin{array}{r}49 \\
77 \\
130\end{array}$ & $\begin{array}{l}84 \cdot 5 \\
87 \cdot 5 \\
97 \cdot 0\end{array}$ \\
\hline Total & & 446 & 345 & $77 \cdot 4$ & 280 & 256 & 91.4 \\
\hline
\end{tabular}

TABLES OF $\chi^{2}$ FOLLIGLES RUPTURED $(\%)$

\begin{tabular}{|c|c|c|c|}
\hline Source & d.f. & $x^{2}$ & $P$ \\
\hline $\begin{array}{l}\text { Between doses } \\
\text { Between durations } \\
\text { Interaction (dose } \times \text { duration) }\end{array}$ & $\begin{array}{l}2 \\
1 \\
2\end{array}$ & $\begin{array}{l}3 \cdot 02 \\
7 \cdot 36 \\
3 \cdot 78\end{array}$ & $\begin{array}{c}\mathrm{ns} \\
<0.01 \\
\mathrm{~ns}\end{array}$ \\
\hline Total & 5 & $14 \cdot 16$ & - \\
\hline \multicolumn{4}{|c|}{ EGGS FERTILIZED $(\%)$} \\
\hline Source & $d . f$. & $x^{2}$ & $P$ \\
\hline $\begin{array}{l}\text { Between doses } \\
\text { Between duration } \\
\text { Interaction (dose } \times \text { duration) }\end{array}$ & $\begin{array}{l}2 \\
1 \\
2\end{array}$ & $\begin{array}{r}2 \cdot 25 \\
30 \cdot 84 \\
9 \cdot 26\end{array}$ & $\begin{aligned} & \mathrm{ns} \\
< & 0.001 \\
< & 0.01\end{aligned}$ \\
\hline Total & 5 & $42 \cdot 35$ & - \\
\hline
\end{tabular}

Pooled data for once-daily and twice-daily injections of HAP.

rupture. Hence at higher doses and after 3 days' treatment a greater proportion of follicles must have ruptured to form corpora lutea (Table 3 ).

Time of onset of oestrus

The mean time of onset of oestrus was 84 to $96 \mathrm{hr}$ after the first HAP injection and there were no significant treatment effects (Table 2). There were marked differences in the ovarian response apparently related to the time of onset of oestrus relative to the last injection of HAP. These occurred regardless of whether treatment was for 2 or 3 days (Table 4). There was a highly significant 
curvilinear relationship between the time of onset of oestrus and the total ovarian response (i.e. corpora lutea and unruptured follicles) with maximum responses occurring in ewes first observed in oestrus 24 to $48 \mathrm{hr}$ after the cessation of treatment $(P<0.001)$. Furthermore in these animals a significantly greater proportion of follicles ruptured to form corpora lutea $(P<0.001)$.

\section{Fertilization}

There was a highly significant effect of duration of treatment on the percentage of recovered eggs which were fertilized, together with a significant

\section{TABLE 4}

RELATIONSHIP BETWEEN THE TIME INTERVAL FROM END OF TREATMENT TO ONSET OF OESTRUS AND THE OVARIAN RESPONSE TO TREATMENT

\begin{tabular}{|c|c|c|c|c|c|}
\hline \multirow[b]{2}{*}{$\begin{array}{c}\text { Time interval } \\
(h r)\end{array}$} & \multirow[b]{2}{*}{$\begin{array}{l}\text { No. } \\
\text { ewes }\end{array}$} & \multicolumn{3}{|c|}{ Mean No. } & \multirow{2}{*}{$\begin{array}{l}(\mathrm{d}) \\
\text { Follicles } \\
\text { ruptured } \\
(\%)\end{array}$} \\
\hline & & $\begin{array}{l}\text { (a) } \\
\text { Corpora } \\
\text { lutea }\end{array}$ & $\begin{array}{c}\text { (b) } \\
\text { Unruptured } \\
\text { follicles }\end{array}$ & $\begin{array}{c}(c) \\
a+b\end{array}$ & \\
\hline $\begin{array}{l}0 \text { to } 24 \\
24 \text { to } 48 \\
48 \text { to } 72 \\
>72\end{array}$ & $\begin{array}{l}15 \\
25 \\
19 \\
10\end{array}$ & $\begin{array}{r}7 \cdot 9 \\
12 \cdot 4 \\
4 \cdot 7 \\
1 \cdot 5\end{array}$ & $\begin{array}{l}5 \cdot 0 \\
2 \cdot 4 \\
3 \cdot 9 \\
1 \cdot 2\end{array}$ & $\begin{array}{r}12 \cdot 9 \\
14 \cdot 8 \\
8 \cdot 6 \\
2 \cdot 7\end{array}$ & $\begin{array}{l}61 \cdot 1 \\
83 \cdot 8 \\
54 \cdot 3 \\
55 \cdot 6\end{array}$ \\
\hline Total & 69 & $7 \cdot 7$ & $3 \cdot 2$ & $10 \cdot 9$ & $70 \cdot 6$ \\
\hline
\end{tabular}

Tests for significance between time intervals for:
(a) Mean numbers of corpora lutea: $\mathbf{F}=10.82 ;$ d.f. $=3,65 ; P<0.001$.
(b) Mean numbers of unruptured follicles; $F=2.42$; d.f. $=3,65$; ns.
(c) Mean numbers of corpora lutea + unruptured follicles; $F=11 \cdot 76$;
d.f. $=3,65 ; P<0.001$.
(d) Percentage of follicles ruptured: $X^{2}=63.39$; d.f. $=3 ; P<0.001$.
Pooled data for 2- and 3-day treatments.

interaction between duration and dose (Table 3). There was a marked reduction in the percentage of eggs fertilized at higher doses of HAP given over 2 days, but not for the 3-day treatments $(P<0.01)$.

There appeared also to be a relationship between the percentage of eggs fertilized and the time interval between end of treatment and onset of oestrus in ewes treated for 2 days (Table 5). The percentage of eggs fertilized in ewes in oestrus within $48 \mathrm{hr}$ was significantly less than in those in oestrus after 48 hr $\left(31.2 \%\right.$ versus $62.3 \% ; \chi^{2}=8 \cdot 77 ;$ d.f. $\left.=1 ; P<0 \cdot 01\right)$. No such relationship was observed in ewes treated for 3 days.

\section{Stage of development of fertilized eggs}

Text-fig. 2 shows the stage of development of fertilized eggs in relation to the time elapsing between the onset of oestrus and egg recovery. There was no significant difference between the distributions of cell stages of eggs recovered from ewes treated for 2 and 3 days. 
TABLE 5

RELATIONSHIP BETWEEN TIME INTERVAL FROM END OF TREATMENT TO ONSET OF OESTRUS AND THE PROPORTION OF EGGS FERTILIZED

\begin{tabular}{|c|c|c|c|c|c|}
\hline \multirow{2}{*}{$\begin{array}{c}\text { Duration of } \\
\text { treatment (days) }\end{array}$} & \multirow{2}{*}{$\begin{array}{c}\text { Time interval } \\
\qquad(h r)\end{array}$} & \multirow{2}{*}{$\begin{array}{l}\text { No. } \\
\text { ewes }\end{array}$} & \multicolumn{2}{|c|}{ No. eggs } & \multirow{2}{*}{$\begin{array}{c}\text { Recovered } \\
\text { eggs } \\
\text { fertilized } \\
(\%) \\
\end{array}$} \\
\hline & & & Recovered & Fertilized & \\
\hline 2 & $\begin{array}{c}0 \text { to } 24 \\
24 \text { to } 48 \\
48 \text { to } 72 \\
>72\end{array}$ & $\begin{array}{r}3 \\
8 \\
13 \\
10\end{array}$ & $\begin{array}{l}15 \\
78 \\
39 \\
14\end{array}$ & $\begin{array}{r}5 \\
24 \\
24 \\
9\end{array}$ & $\begin{array}{l}33 \cdot 3 \\
30 \cdot 8 \\
61 \cdot 5 \\
64 \cdot 3\end{array}$ \\
\hline Total & & 34 & 146 & 62 & $42 \cdot 5$ \\
\hline 3 & $\begin{array}{c}0 \text { to } 24 \\
24 \text { to } 48 \\
48 \text { to } 72 \\
>72\end{array}$ & $\begin{array}{r}12 \\
17 \\
6 \\
0\end{array}$ & $\begin{array}{r}87 \\
171 \\
22 \\
-\end{array}$ & $\begin{array}{r}74 \\
161 \\
21 \\
-\end{array}$ & $\begin{array}{l}85 \cdot 1 \\
94 \cdot 2 \\
95 \cdot 5 \\
-\end{array}$ \\
\hline Total & & 35 & 280 & 256 & $91 \cdot 4$ \\
\hline
\end{tabular}

TABLE OF $x^{2}$

\begin{tabular}{|c|c|c|c|}
\hline Source & d.f. & $x^{2}$ & $P$ \\
\hline $\begin{array}{l}\text { Between durations } \\
\text { Between time intervals } \\
\text { Interaction (duration } \times \text { time } \\
\text { interval) }\end{array}$ & $\begin{array}{l}1 \\
3 \\
3\end{array}$ & $\begin{array}{r}30 \cdot 81 \\
0.31 \\
4.80\end{array}$ & $\begin{array}{c}<0 \cdot 001 \\
\text { ns } \\
\text { ns }\end{array}$ \\
\hline Total & 7 & 35.92 & - \\
\hline
\end{tabular}

Pooled data for once-daily and twice-daily HAP treatments.

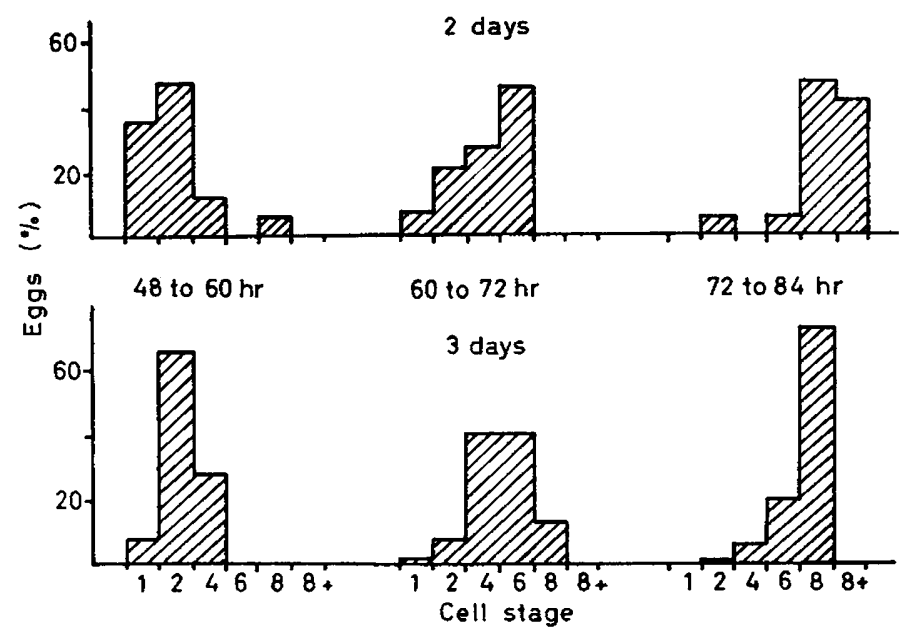

Text-Fig. 2. Cell stage of fertilized eggs in relation to time interval: onset of oestrus to recovery. 


\section{DISCUSSION}

The general nature of the dose-response relationships for HAP, in terms of numbers of ovulations appears to be similar to that reported by Robinson (1951a) and Wallace (1954) for PMs over the dose range of 500 to 2000 i.u. However, whereas Robinson observed a tendency towards an increase in the numbers of unruptured luteinized follicles in ewes treated with the higher doses of PMS, no such tendency was observed with HAP. The mean number of unruptured follicles was substantially the same at all doses of HAP.

Prolonged stimulation with HAP appears to be necessary to induce a maximum ovulatory response in the ewe, whereas with PMS a single injection on the 11 th to the 13th day of the oestrous cycle is all that is necessary (Robinson, 1951b). Presumably HAP is more rapidly inactivated than PMS. Although stimulation for 3 days was much more effective than a 2-day treatment, dividing the daily dose had no further beneficial effect. Once-daily injections of HAP appear to be sufficiently frequent to maintain the optimum circulatory level of gonadotrophin.

The ovarian response to HAP varied with the time elapsing between the end of treatment and the onset of oestrus. Total ovarian responses (i.e. numbers of corpora lutea and unruptured follicles) reached a maximum in ewes in oestrus 24 to $48 \mathrm{hr}$ after the cessation of treatment. Furthermore, in these animals a higher proportion of follicles ruptured to form corpora lutea. However, there was no evidence of any real difference in the numbers of unruptured follicles in ewes in oestrus at various times relative to the end of treatment. It is apparent that the process of ovulation, even of large numbers of follicles, in the ewe is not a major limiting factor following HAP stimulation.

Fertilization was also affected by the duration of stimulation, there being a marked decrease in the percentage of the recovered eggs which were fertilized, after higher doses of HAP administered over 2 days. Fertilization also varied with the time elapsing between cessation of 2 days' treatment and the onset of oestrus. The percentage of eggs fertilized in ewes in oestrus within $48 \mathrm{hr}$ of the cessation of the 2-day treatments was only one-half that observed in ewes in oestrus after an interval of more than $48 \mathrm{hr}$. In ewes treated for only 2 days and in oestrus soon after treatment, maturation of the eggs may not have been sufficiently advanced by the time of ovulation to permit fertilization.

HAP appears at least as effective as PMS for the induction of multiple ovulation in the ewe. Any advantage to be gained from its use would arise from the apparently more reliable ovarian response to higher doses. This is particularly valuable when large numbers of eggs are required, as in egg transfer work. Its major disadvantage is the number of injections required.

\section{ACKNOWLEDGMENTS}

This work was partly financed by the Sheep and Wool Research Committee of Australia, to whom grateful acknowledgment is made. Valuable technical assistance was provided by Mr B. J. Carlin. Thanks are due to the Management and Staff of Burns Animal Food Company, Sydney, from whose slaughterhouse the pituitaries were collected. 


\section{REFERENGES}

Casida, L. E., WARWick, E. J. \& MEYer, R. K. (1944) Survival of multiple pregnancies induced in the ewe following treatment with pituitary gonadotrophins. F. Anim. Sci. 3, 22.

Hammond, J., JnR., Hammond, J. \& Parkes, A. S. (1942) Hormonal augmentation of fertility in sheep. I. Induction of ovulation, superovulation and heat in sheep. F. agric. Sci. 32, 308.

Moore, N. W. \& Shelton, J. N. (1962) Oestrous and ovarian response of the ewe to a horse anterior pituitary extract. Nature, Lond. 194, 1283.

Murphree, R. L., Warwick, E. J., Ciasida, L. E. \& McShan, W. H. (1944) Potential fertility of ova from ewes treated with gonadotrophins. J. Anim. Sci. 3, 12.

RAdFord, H. M., Watson, R. H. \& Wood, G. F. (1960) A crayon and associated harness for the detection of mating under field conditions. Aust. vet. F. 36, 57.

Robinson, T. J. (1951a) The control of fertility in sheep. Part II. The augmentation of fertility by gonadotrophin treatment of the ewe in the normal breeding season. J. agric. Sci. 41, 6.

Robinson, T. J. (1951b) Reproduction in the ewe. Biol. Rev. 26, 121.

Thibault, C., Ortavant, R. \& Laplaud, M. (1948) Recherches sur la superovulation experimentale chez la brebis. Ann. Endocrinol. 9, 83.

WALLACE, L. R. (1954) Studies in the augmentation of fertility of Romney ewes with pregnant-mare serum. J. agric. Sci. 45,60 . 